\title{
CHARAKTERYSTYKA ZESPOLU ARCHIWALNEGO „KONVENTO POLONIA AKTAI” W BIBLIOTECE LITEWSKIEJ AKADEMII NAUK IM. WRÓBLEWSKICH W WILNIE
}

Konwent Polonia powstał w 1828 r. w Dorpacie (dzisiejsze Tartu w Estonii) i funkcjonuje do czasów obecnych jako najstarsza polska korporacja akademicka. Jego losy w latach 1828-1918 były dość burzliwe, na co wpływ miała sytuacja korporacji w okresie zaborów ${ }^{1}$. W dwudziestoleciu międzywojennym natomiast ruch korporacyjny rozkwitł, a korporacje stały się jednymi z najistotniejszych organizacji studenckich II RP. Sam Konwent Polonia przeniósł się do Wilna, gdzie działał do początków II wojny światowej.

Niniejsze opracowanie stanowi kontynuację badań nad dorobkiem ruchu korporacyjnego w Polsce, który do czasów obecnych zachował się w nieznacznej ilości. Przy tym archiwum Konwentu Polonia stanowi najobszerniejszy zachowany zbiór dokumentacji, dotyczący działalności jednej korporacji. Dotychczas opracowane zostały zagadnienia dotyczące archiwaliów Konwentu zgromadzonych w Archiwum Archidiecezjalnym Warszawskim ${ }^{2}$ oraz Instytucie Polskim i Muzeum im. gen. Sikorskiego w Londynie ${ }^{3}$. Trzecim najistotniejszym zbiorem dokumentacji tej korporacji jest zespół archiwalny przechowywany w Bibliotece Litewskiej Akademii Nauk im. Wróblewskich w Wilnie.

To właśnie tam w trakcie II wojny światowej została zabezpieczona większość dokumentacji dorpackiej a także wileńskiej Konwentu. Pierwotnie przekazano ją jako depozyt, który po wojnie zostanie odebrany przez nowe władze Konwentu. Jak się okazało w przyszłości, nie było to już możliwe, zaś zbiory zostały przejęte przez państwo litewskie. Instytucja przechowywująca wspomniane zbiory przechodziła na przestrzeni lat restrukturyzacje, które związane były m.in. z sytuacją polityczną. Obecnie funkcjonuje pod nazwą Biblioteka Litewskiej Akademii Nauk im. Wróblewskich i mieści się w Wilnie przy Žygimantų g. 1.

Zespół został opracowany w 1954 r., pierwotnie nadano mu sygnaturę KPA ${ }^{4}$.[numer kolejny]. Obecnie znajduje się pod sygnaturą F.160-[numer kolejny] ${ }^{5}$. W chwili opracowania

O losach Konwentu Polonia w latach 1828-1918 pisał m.in. Arkadiusz Janicki: A. Janicki, M. Laszczkowski, Polskie korporacje baltyckie przed 1918 rokiem, Warszawa 2011, s. 42-63.

Artykuł „Zespół archiwalny Konwent Polonia jako źródło archiwalne” został złożony do druku.

Artykuł „Zespół Korporacja Akademicka Konwent Polonia w Instytucie Polskim i Muzeum im. gen. Sikorskiego - uwagi” został złożony do druku i zostanie wydrukowany w czasopiśmie „Teki archiwalne”.

KPA - Konvento Polonia aktai.

5 Litera F, w sygnaturze w tym wypadku oznacza ,fonds d' archive” (fr.) - zespół. 
wszelkie pomoce ewidencyjne przygotowano w języku rosyjskim i od tego momentu prawdopodobnie nie zostały one uzupełnione ani zaktualizowane. Powstały wówczas rosyjskojęzyczny (w większości) inwentarz kartkowy jest jedyną pomocą ewidencyjną do omawianego zespołu archiwalnego. Przy jego konstruowaniu również doszło do pewnej niekonsekwencji, bowiem nie ujednolicono języka wykorzystywanego do tworzenia kart inwentarzowych. W ten sposób tytuły wyłącznie w języku rosyjskim znajdują się na kartach inwentarzowych następujących jednostek: 1-69, 71-72, 74-76, 78-79, 84, 86-94, 96, 111-112, 114-126, 138, 146, 192, 195-196, 199-204, 206-207,209-213, 215, 218, 220-225, 227-228, 230-233, 250, 253-254, 267, 287, 290-291, 294, 297-312, 323, 327, 332, 360-362, 365-369, 371-374, 376, 380, 385, 389, 393-397, 400; te wyłącznie w języku polskim: 70, 108-110, 149-150, 152-158, 160-163, 165-168, 171-172, 174-176, 178, 180-185, 188-191, 205, 208, 214, 216-217, 219, 226, 235-239, 248, 251-252, 255-257, 259-266, 268-286, 288-289, 296, 314-318, 320, 324-326, 328-331, 384, 386-388, 391, 399; zaś dwujęzyczne polsko-rosyjskie: 73, 77, 80-83, 85, 95, 97-107,113, 127-137, 139, 141-145, 147-148, 151, 159, 164, 169-170, 173, 177, 179, 186-187, 193-194, $197-$ 198, 229, 234, 240-247, 249, 258, 292-293, 295, 313, 319, 322, 363-364, 377, 398. Nieliczne materiały posiadają tytuły lub fragment tytułu w języku niemieckim: 333, 336, 340-342, 345-357, 370, 375, 378-379, 381, 383, 390, dwujęzyczne niemiecko-rosyjskie: 321, 334-335, 337-339, 343-344, 358-359, 382, 392, bądź niemiecko-litewskie: 402-404. Ostatnimi typami będą tytuły polsko-litewsko-rosyjskie: 140, bądź też polsko-litewskie: 401. Różny język tytułów jednostek byłby całkowicie zrozumiały, gdyby odpowiadał zawartości jednostek, w tym jednak wypadku mamy do czynienia z sytuacją, kiedy dla części jednostek zachowano oryginalne nazwy teczek, zaś dla części je zmieniono ${ }^{6}$.

Późniejsze poprawki w opracowanym zespole (koniec XX - początek XXI w.), wiązały się raczej z uzupełnieniem brakującej lub błędnej foliacjī. Informują o tym uwagi zamieszczone w metryczce jednostki archiwalnej. Tego typu błędy techniczne zostały prawdopodobnie odnalezione w trakcie udostępniania zespołu użytkownikom ${ }^{8}$. Przy tym należy zaznaczyć, iż poprawki nie wiążą się z fizycznym usunięciem błędnej numeracji, ale właściwa foliacja została naniesiona tuż obok starej, która została przekreślona9. W sytuacji kiedy nie naniesiono foliacji na karty, nie poprawiano całości numeracji, ale dodawano dodatkowe numery, oznaczając je przy pomocy kolejnych liter alfabetu łacińskiego. Niewykluczone, że i te poprawki zostały naniesione w rezultacie udostępniania zbiorów użytkownikom. Oczywiście prowadzi to do sytuacji, w której informacja znajdująca się w metryczce staje się zdezaktualizowana, co jednak rozwiązano poprzez dodanie stosownej informacji w polu pastabos (uwagi).

W kwestii opracowania należy zaznaczyć, iż w trakcie porządkowania zespołu nie została wypracowana jednolita metoda. Dotyczy to zarówno poziomu selekcji materiałów archiwalnych oraz tworzenia z nich jednostek archiwalnych, a także nadawania układu wewnętrznego

\footnotetext{
6 Inwentarz archiwalny znajdujący się w BLAN przyjmuje jeszcze formę inwentarza kartkowego i nie jest udostępniany powszechnie w Internecie. $Z$ tego też względu autor nie zdecydował się na jego upublicznienie.

7 Zespół został również przynajmniej częściowo przepakowany. Część jednostek przechowywana jest w obwolutach, które jednocześnie pełnią funkcję metryczek poszczególnych jednostek archiwalnych. Dodatkowo niektóre jednostki zostały zszyte i oprawione.

8 Taką tezę możemy wysnuć, porównując termin nanoszenia poprawek wraz z terminem wykonania kserokopii $\mathrm{z}$ danej jednostki.

9 Dotyczy to np. jednostki F.160-16.
} 
jednostkom. Bardzo dobrym przykładem takiego postępowania jest bardzo bogata korespondencja, z której utworzono jednostki: F.160-5 - F.160-69, F.160-71 - F.160.72, F.160-74, F.160-78-F.160-82, F.160-86-F. 160-94, F.160-205, do której oczywiście można również włączyć dzienniki korespondencyjne, znajdujące się pod sygnaturami: F.160-210 - F.160-213. Niestety nie została ona w żaden logiczny sposób ułożona, na co wskazuje dość chaotyczne rozrzucenie po całym zespole. Stosunkowy chaos w teczkach oraz doświadczenie wynikające z pracy z dokumentacją Konwentu z AAW sugeruje, iż w trakcie zabezpieczania zbiorów Konwentu podczas II wojny światowej, mogło dojść do pomieszania zbiorów, przekazanych do BLAN. Niestety w trakcie prac archiwalnych nie podjęto wystarczających działań mających na celu uporządkowanie dokumentacji. Wskazuje na to brak poszlak pozwalających ustalić, jaką metodą opracowania kierował się archiwista. $Z$ bieżącego układu jednostek nie jesteśmy w stanie określić struktury komórek funkcjonujących w ramach Konwentu, tak samo ciężko znaleźć ślady tworzenia grup tematycznych.

Pomijając kwestię wydzielania poszczególnych jednostek archiwalnych, w niektórych jednostkach brakuje również wewnętrznego ładu, co można osiągnąć chociażby poprzez nadanie układu chronologicznego, który bywa zachwiany ${ }^{10}$. Osoba opracowująca zespół wydaje się, że nie przyjęła na wstępie jednej obowiązującej zasady dotyczącej nadawania układu chronologicznego - czy ma być malejący, czy rosnący. Wskazuje na to występowanie obydwu tych sposobów opisu.

Na zespół składają się łącznie 404 jednostki inwentarzowe, przy czym część z nich dzieli się na kilka jednostek archiwalnych ${ }^{11}$. Niestety przyczyny, dla których jednostki archiwalne nie odpowiadają jednostkom inwentarzowym, są niejasne. Wydawałoby się, że mogłoby to wynikać z potrzeby rozdzielenia dokumentacji różnorodnej tematycznie, albo ze zbyt dużej objętości jednostki ${ }^{12}$. Jednakże w tym wypadku żadna $\mathrm{z}$ tych okoliczności nie zachodzi.

Do opisu niniejszej dokumentacji zostaną zastosowane dwa kryteria: chronologiczne oraz rzeczowe. W przypadku pierwszego możliwe będzie rozróżnienie, do jakiego okresu dana dokumentacja należy: dorpackiego czy też wileńskiego, zaś drugi pomoże w zaprezentowaniu różnorodności zgromadzonych archiwaliów. Pozwoli to na uzyskanie odpowiedzi na pytanie, w jakim stopniu części archiwum konwentowego w AAW oraz BLAN są ze sobą zbieżne oraz w jakim stopniu się uzupełniają.

Za dokumentację okresu dorpackiego możemy przyjąć tę do roku 1918, a więc z jednej strony do momentu zakończenia I wojny światowej i powrotu państwa polskiego na mapę Europy, a także do przeniesienia siedziby z Dorpatu do Wilna, co nastąpiło w roku 1919. Składa się na nią 140. jednostek: F.160-1 - F.160-7, F.160-73, F.160-75, F.160-77, F.160-83, F. 160-84, F.160-96 - F.160-98, F.160-109, F.160-110, F.16-123, F.160-126, F.160-131, F.160-145, F.160-148, F.160-149, F.160-180 - F.160-186, F.160-189-F.160-192, F.160-194, F.160-198, F.160-214, F.160-216, F.160-235 - F.160-247, F.160-250, F.160-255 - F.160-257,

\footnotetext{
10 Przykładem może być chociażby jednostkaF.160-81, na którą składają się odpisy pism wychodzących z lat 1928-1930. Znajdują się tam dwa odpisy listu do H.J. hr Colonna-Czosnowskiego, którym nawet zostały nadane identyczne znaki pisma: 263/30. Jeden z nich powstał w formie rękopisu, zaś po jego przepisaniu na maszynie powstała druga wersja. Wersja późniejsza znajduje się na kartach 79-80v, zaś ta wcześniejsza na stronach 45-46.

11 Na przykład jednostka inwentarzowa F.160-64, dzieli się na trzy jednostki archiwalne: F.160-64/1, F.160-64/2 i F.160-64. Identyczna sytuacja zachodzi m.in. w: F.160-65 (3 j.a.), F.160-86 (2 j.a.) i F.160-99 (4 j.a.).

12 W przypadku dużej różnorodności dokumentów, wskazane byłoby jednak przeprowadzenie dokładniejszej klasyfikacji i stworzenie odrębnych jednostek.
} 
F.160-313 - F.160-324, F.160-326, F.160-327, F.160-330 - F.160-360, F.160-362, F.160-365F.160-376, F.160-378 - F.160-396, F.160-402 - F.160-404. Jednostek zawierających dokumentację z obydwu okresów jest zaledwie 18.: F.160-13, F.160-71, F.160-124, F.160-127, F.160-133, F.160-143, F.160-197, F.160-200 - F.160-202, F.160-208, F.160-221, F.160-226, F.160-234, F.160-248, F.160-249, F.160-312, F.160-400. W przypadku zaś trzech jednostek zakres chronologiczny nie został ustalony: F.160-193, F.160-195, F.160-199. Pozostałe jednostki w liczbie 243. stanowią okres wileński. Jak więc widać, na okres dorpacki składa się przeszło $33 \%$ jednostek inwentarzowych ${ }^{13}$, co nie znalazło jakiegokolwiek odzwierciedlenia w strukturze zespołu.

Kryterium rzeczowe daje dużo doskonalsze spojrzenie na zgromadzone zbiory. Można wyróżnić kilkanaście głównych grup rzeczowych:

- Akta sekretarskie (F.160-1 - F.160-4, F.160-83, F.160-131)

- Korespondencja: przychodząca (F.160-5 - F.160-69, F.160-71, F.160-72, F.160-78, F.160-79, F.160-86, F.160-87, F.160-89, F.160-90, F.160-397), wychodząca (F.160-74, F.160-80 - F.160-82, F.160-88, F.160-91 - F.160-94), dzienniki korespondencyjne (F.160-210 - F.160-213)

- Akta sądowe: Stały Sąd Honorowy (F.160-95, F.160-99, F.160-100 - F.160-107, F.160-109, F.160-140), Stały Sąd Konwentowy (F.160-124, F.160-218)

- Protokoły i sprawozdania (F.160-110, F.160-111, F.160-123, F.160-125, F.160-126, F.160-138, F.160-144, F.160-145)

- Akta normatywne: statuty i regulaminy (F.160-130, F.160-132, F.160-134-F.160-137)

- Materiały dotyczące działalności w ZPKA (F.160-108, F.160-112, F.160-113 - F.160 122, F.160-128, F.160-134, F.160-139, F.160-142)

- Materiały dotyczące obchodów 100-lecia (F.160-76, F.160-204-F.160-207, F.160-217)

- Dokumentacja finansowa (F.160-73, F.160-96 - F.160-98, F.160-127, F.160-143, F.160202, F.160-208, F.160-209, F.160-226, F.160-234, F.160-312 - F.160-322, F.160-324 F.160-330, F.160-384 - F.160-387, F.160-391 - F.160-396, F.160-399 - F.160-400)

- Dokumentacja Biblioteki (F.160-214, F.160-235 - F.160-252, F.160-254 - F.160-257)

- Spisy członków (F.160-215, F.160-216, F.160-219-F.160-223, F.160-227 - F.160-233)

- Dokumentacja osób nieprzyjętych i byłych członków (F.160-224, F.160-225, F.160-331)

- Księgi obecności (F.160-258 - F.160-311)

- Referaty fuksowskie i barwiarskie (F.160-146 - F.160-199)

- Notatki z wykładów (F.160-332 - F.160-360, F.160-362 - F.160-383, F.160-401 - F.160-404)

- Inne (F.160-70, F.160-75, F.160-77, F.160-84, F.160-85, F.160-129, F.160-133, F.160141, F.160-200, F.160-201, F.160-253, F.160-323, F.160-361, F.160-388 - F.160-390, F.160-398, F.160-401 - F.160-404)

Pierwsza wymieniona grupa tematyczna - „Akta sekretarskie” składa się z 6 j.a., które chronologicznie obejmują lata 1895-1910, 1912-1917, stanowią więc uzupełnienie dokumentacji tego samego typu zgromadzonej w AAW (lata 1883-1898). Występują zarówno w formie poszytu (F.160-1, F.160-83, F.160-131), jak i luźnych kart. Tak jak w przypadku

\footnotetext{
13 W podanych 33\% nie uwzględniono jednostek, w których znajduje się dokumentacja z obydwu okresów, a także trzech jednostek z nieustaloną chronologią.
} 
dokumentacji warszawskiej, na Akta składa się przede wszystkim korespondencja wraz z przesłanymi załącznikami.

Uzupełnieniem akt sekretarskich w okresie dorpackim były zbiory korespondencji, stanowiące druga grupę rzeczową, listy nie były jednak wklejane do poszytu, tak jak to miało miejsce w przypadku powyższym. Dla okresu dorpackiego wydzielono zaledwie trzy jednostki z korespondencją przychodzącą (F.160-5 - F.160-7) z lat 1909-1917 oraz dwie z listami z obydwu omawianych okresów (F.160-13, F.160-71) z lat 1917-1939. Co charakterystyczne, w okresie wileńskim zaniechano wydzielania akt sekretarskich, pozostając przy zbiorach korespondencji. Być może wynikało to ze znacznego zwiększenia się ilości pism przychodzących, związanego z rozwojem ruchu korporacyjnego i pojawienia się wielu nowych korporacji, a także powstania innych instytucji, z którymi utrzymywano kontakt. Ten sam fakt zapewne był przyczynił się do korzystania z dziennika korespondencyjnego, w celu uporządkowania znacznej ilości pism przechodzących przez kancelarię Konwentu.

Zebrana korespondencja jest różnorodna. Zawiera zarówno pisma oficjalne, przesyłane przez: władze ZPKA, Miejscowe Koła Międzykorporacyjne, korporacje (skartelowane oraz pozostałe), władze uczelni oraz inne urzędy państwowe, jednostki wojskowe, jak i prywatne - od kół filisterskich, Polonusów (czynnych i filistrów). Również treść jest bardzo interesująca dla badacza, pozwala bowiem uzyskać informacje dotyczące składu prezydiów innych korporacji ${ }^{14}$, ich relacji z Konwentem i innymi korporacjami, czy stosunku do ZPKA. Jest to osiągalne z racji na fakt członkostwa Polonii w strukturach ogólnokorporacyjnych, a także utrzymywanie stosunków z licznymi korporacjami - zwłaszcza z kręgu wileńskiego. Możliwa jest również analiza działalności redakcji „Wiadomości Korporacyjnych”, która przesyłała stosunkowo liczne wiadomości, ponaglenia czy rozliczenia.

Znaczną część korespondencji stanowią wszelkiego rodzaju zaproszenia - przede wszystkim na bale organizowane przez inne korporacje, jednostki wojskowe lub stowarzyszenia o charakterze branżowym ${ }^{15}$, ale również śluby, spotkania dyskusyjne oraz inne. Oprócz tradycyjnych listów, można tutaj znaleźć stosunkowo liczne telegramy ${ }^{16}$.

Odrębne zagadnienie stanowi korespondencja wychodząca (F.160-74, F.160-80 - F.160 82, F.160-88, F.160-91 - F.160-94) oraz dzienniki korespondencyjne (F.160-210 - F.160-213), uzupełniające informacje o relacjach z innymi podmiotami, w tym przede wszystkim korporacjami.

Kolejny dział tematyczny mogą stanowić akta sądowe, na które składają się dokumenty wytworzone przez Stały Sąd Honorowy (F.160-95, F.160-99, F.160-100 - F.160-107,

14 Przyjętym zwyczajem było rozsyłanie wiadomości do innych korporacji - tych, z którymi utrzymywano stosunki, o składzie nowo wybranego prezydium. Dzięki temu członkowie Konwentu systematycznie otrzymywali informacje od kilkunastu/kilkudziesięciu korporacji o nowych władzach. Konwent również przesyłał tego typu informację do znacznej ilości korporacji; BLAN, F.160-210-F.160-213.

15 Konwent był zapraszany m.in. przez: Wileńskie Koło Młodych Ziemianek (na „czarną kawę” w dniu 13 lutego 1927 r.), Dowódcę, Oficerów i Podchorążych Oficerskiej Szkoły Kawalerji w Grudziądzu (na Bal Podchorążych w dniu 8 lutego 1927 r.), Koło Studentów Rosjan USB (na Doroczny Koncert - Bal w dniu 16 lutego 1928 r.) czy też Oddział Wileńskiego Stowarzyszenia Urzędników Państwowych w dniu 1 marca 1924 r.); BLAN: F.160-52, k. 27, F.160-16, k. 80, F.160-42, k. 50, F.160-11, k. 60.

16 Historyk, prowadząc badania w oparciu o korespondencję, musi się wykazać dużą dozą cierpliwości. Jak wspomniano wcześniej, nie zastosowano żadnego podziału treściowego korespondencji, zaś podział chronologiczny również jest wątpliwej jakości. Dla przykładu korespondencja przychodząca z roku 1923 znajduje się w 5. jednostkach (F.160-8 - F.160-10, F.160-13, F.160-16), zaś ta z roku 1927 w 16. (F.160-17 -F.160-20, F.160-23, F.160-27, F.160-42, F.160-46-F.160-53, F.160-397). 
F.160-109, F.160-140), jak i Stały Sąd Konwentowy (F.160-124, F.160-218). W przypadku SSH znaczną część stanowią rachunki (F.160-95, F.160-99, F.160-140). Chronologicznie dokumentacja ta dotyczy okresu 1897-1918 oraz 1923-1934, przy czym sprawy opisywane w protokołach związane są przede wszystkim z finansową stroną działalności Konwentu, w tym działalności jako komisja rewizyjna. W przypadku SSK obydwie jednostki zawierają protokoły z lat $1916-1934$.

Następnymi wartymi uwagi źródłami są protokoły i sprawozdania (F.160-110, F.160-111, F.160-123, F.160-125, F.160-126, F.160-138, F.160-144, F.160-145). Pierwszą jednostką wartą omówienia jest księga rozporządzeń, uchwał, praw i protokołów w Dorpacie (F.160-110), zawierająca materiały z lat 1897-1918. W jej skład wchodzą m.in. wykazy urzędników konwentowych. Nie jest to bynajmniej jedyna jednostka zawierająca materiały z okresu dorpackiego. Niezwykle interesujący jest spisany w całości po rosyjsku poszyt zawierający protokoły posiedzeń konwentu z lat 1913-1917 $7^{17}$. Jak przypuszcza Jan Trynkowski, mogła ona służyć do przedstawiania władzom uczelni sprawozdań z działalności konwentu. Bliższe prawdy będą protokoły polskojęzyczne z okresu 1914-1917, znajdujące się w jednostce F.160-145. Ich uzupełnieniem może być poszyt figurujący pod sygnaturą F.160-126 zawierający protokoły z 1918 r., przy czym należy zaznaczyć, iż nie jest on jednolity treściowo, ponieważ znajduje się w nim również korespondencja z 1918 r. Protokoły i sprawozdania z okresu wileńskiego zawierają się w jednostkach F.160-111, F.160-125, F.160-138, F.160-144 i dotyczą okresu 1921-1939 (protokoły) lub 1921-1937 (sprawozdania). Tak jak w przypadku korespondencji, w części jednostek poszczególne dokumenty nie zostały ułożone chronologicznie przed sfoliowaniem (np. F.160-111).

Występujące w jednostkach kolejnych akta normatywne zawierają statuty: Konwentu Polonia z 1925 r. (F.160-135), Welecji (F.160-132), a także trzy statuty ZPKA z: 15 czerwca 1922 r., 4 maja 1931 r. oraz 20 stycznia 1932 r. (F.160-134), projekt statutu Związku Narodowego Polskiej Młodzieży Akademickiej (F.160-137), a także regulamin Wileńskiego Koła Międzykorporacyjnego (F.160-136). Ostatnia jednostka (F.160-130) składa się z wielu statutów oraz regulaminów.

Stosunkowo licznie reprezentowane są również materiały dotyczące ZPKA. Składają się na nie protokoły ze Zjazdów ZPKA: II Zjazdu ZPKA w dniu 4 maja 1922 r. (F.160-122), III Zjazdu ZPKA w dniach 7-10 maja 1923 r. (F.160-117), IV Zjazdu ZPKA w dniach 8-12 maja 1924 r. (F.160-118), V Zjazdu ZPKA w dniach 7-11 maja 1925 r. (F.160-119), VI Nadzwyczajnego Zjazdu ZPKA w dniach 20-22 listopada 1925 r. (F.160-120), VII Zjazdu ZPKA w dniach 28 stycznia-1 lutego 1927 r. (F.160-121), VIII Zjazdu ZPKA w dniach 7-9 grudnia 1928 r. (F.160-114), IX Zjazdu ZPKA w dniach 6-8 grudnia 1930 r. (F.160-108), X Zjazdu ZPKA w dniach 8-10 grudnia 1932 r. (F.160-112), a także ze Zjazdów Rady Naczelnej ZPKA: I Zjazdu Rady Naczelnej ZPKA w dniach 5-6 czerwca 1927 r. (F.160-116), III Zjazdu Rady Naczelnej ZPKA z 7 grudnia 1928 r. (F.160-114) ${ }^{18}$, V Zjazdu Rady Naczelnej ZPKA z 1930 r. (F.160-115), VI Zjazdu Rady Naczelnej ZPKA w dniach 21-22 listopada 1931 r.

\footnotetext{
17 W przypadku wspomnianej wersji, w języku rosyjskim zapisano również nazwiska członków Konwentu Polonia.

18 W jednostce F.160-114 zgromadzono zarówno protokół z VIII Zjazdu ZPKA, jak i z posiedzenia III Rady Naczelnej ZPKA, które odbyły się w tym samym terminie.
} 
(F.160-121) ${ }^{19}$. Poza tym zgromadzono sprawozdania ZPKA z okresu 1928-1930 (F.160-128), protokoły z Konferencji przedstawicieli środowisk korporacyjnych, która odbyła się w $1926 \mathrm{r}$. (F.160-113) oraz liczne Okólniki ZPKA z lat 1922-1933 (F.160-139, F.160-142) 20. Całość daje pewne spojrzenie na funkcjonowanie ZPKA oraz ewolucję tej organizacji.

Dla działalności Konwentu niezwykle interesujące są wszelkie zestawienia finansowe. Co charakterystyczne, reprezentują one przede wszystkim okres dorpacki, co wynika z faktu, iż w okresie wileńskim większość rachunków i pokwitowań była włączana w skład dokumentacji SSH, pełniącego również obowiązki komisji rewizyjnej. Znaczną część zebranych materiałów stanowią wykazy związane z prowadzoną przez Konwent kuchnią/bufetem. Są to z jednej strony wykazy długów, ale także wydatki kuchni związane z przygotowywanymi posiłkami, które obejmują okres 1886-1930 (F.160-96, F.160-98, F.160-99, F.160-208, F.160-226, F.160-312, F.160-325, F.160-329, F.160-330). W pewnym stopniu uzupełnienie wykazów bufetu stanowią rachunki związane zarówno z organizacją knajp ogólnych w latach 1913-1918 (F.160-319), jak i oficjalnych przyjęć w latach 1916-1917 (F.160-324). Także stosunkowo rozbudowana jest dokumentacja kasy rozchodowej, która obejmuje lata 1884-1924 (F.160-234, F.160-313 - F.160-318, F.160-326). Dwie jednostki dotyczą również zagadnień stypendium w latach 1893-1902 (F.160-320, F.160-386), a trzy kolejne zawierają księgi kwaterunkowe z lat 1906-1907, 1911-1917 (F.160-327, F.160-393, F.160-394). Nie brakuje również zestawień dość specyficznych, takich jak: księga dobrowolnych ofiar z lat 1881-1928 (F.160-143), kasy reprezentacyjnej z lat 1908-1916 (F.160-384), spisu papierów procentowych kasy budowlanej z lat 1912-1915 (F.160-385), kasy oberfuksowskiej za okres 1908-1918 (F.160-387), wykazów składek filisterskich z 1913-1917 r. oraz 1921 r. (F.160-391, F.160-328) ${ }^{21}$, Conto-Buch (F.160-321, F.160-392), dokumentacji dotyczącej rachunku w Wileńskim Prywatnym Banku Handlowym z lat 1906-1916 (F.160-395) oraz wykazu towarów zakupionych na kredyt w latach 1904-1905 (F.160-396). Na pozostałe materiały składa się dokumentacja o większym stopniu ogólności, taka jak: sprawozdania kasy Konwentu z lat 1888-1937 (F.160-127), rachunki sekretarskie z lat 1917-1918, księgi kasowe z lat 1919-1920 oraz 1925-1926 (F.160-209, F.160-299), a także inne rachunki i pokwitowania z lat 1878-1881, 1893-1927 (F.160-73, F.160-202, F.160-400).

Część rachunków dotyczy również działalności kasy bibliotecznej w latach 1878-1903 (F.160-238), 1906-1918 (F.160-255), 1928-1931 (F.160-251). Dokumentacja finansowa z lat 1900-1925 wchodzi również w skład jednostki F.160-249, gdzie znajdują się rachunki za nabyte książki ${ }^{22}$. Poza tym w ramach dokumentacji wytwarzanej przez bibliotekarza w zespole znajduje się rejestr wypożyczeni z lat 1922-1923 (F.160-254), księga abonentów z lat 1904-1909 (F.160-256), ale przede wszystkim liczne katalogi biblioteczne (F.160-214, F.160-235 - F.160-237, F.160-239 - F.160-248, F.160-250, F.160-252, F.160-257). Należy mieć przy tym na uwadze, iż znaczna część katalogów dotyczy zbiorów zgromadzonych w końcu XIX w. oraz pierwszych latach XX w. Są to więc katalogi dalece nieaktualne.

\footnotetext{
19 W jednostce F.160-121 zgromadzono zarówno protokół z VI Zjazdu Rady Naczelnej ZPKA, jak i z VII Zjazdu ZPKA.

${ }^{20}$ W jednostkach F.160-139 oraz F.160-142 zgromadzono również pismo o wystąpieniu Konwentu Polonia z ZPKA z 1933 r. oraz Protokół I Zjazdu Rady Naczelnej ZPKA w dniach 5-6 czerwca 1927 r.

21 Jeszcze jeden wykaz składek filisterskich z 1921 r. znajduje się w jednostce F.160-312.

22 W jednostce F.160-249 znajduje się równie plan pracy bibliotekarza.
} 
Odrębny dział może stanowić także dokumentacja, dotycząca organizacji jubileuszu 100-lecia korporacji, której członkowie poświęcili wiele uwagi. Obejmuje ona właściwie całokształt prac związanych z organizacją, a także przebiegiem obchodów - począwszy od zachowanych blankietów zaproszeń (F.160-206) i bezpośrednio z tym związana korespondencja dotycząca ustalania liczebności i składu delegacji, a także sposobu ich rozmieszczenia podczas obchodów (F.160-204). Zachowano również część korespondencji wychodzącej, która skierowana do filistrów dotyczyła strony organizacyjnej, w tym aspektów finansowych (F.160-205). W dniu obchodu, a także po nim, przesyłano liczne listy i telegramy gratulacyjne - zarówno od innych korporacji, jak i filistrów (F.160-207). Z samych obchodów zachowało się spisane odręcznie przemówienie fil. Bohdana Wydżgi, liczące 45 k. (F.160-217), zaś sprawozdania i wspomnienia z obchodów zawiera jednostka F.160-76 ${ }^{23}$.

Następną grupę tematyczną stanowi ewidencja członków (F.160-215, F.160-216, F.160219 - F.160-223, F.160-227 - F.160-233), która w różnym zakresie dotyczy lat 1916-1938. Wpisują się w nią zarówno spisy członków, jak i filistrów Konwentu. Dość charakterystyczną jednostką jest F.160-219, która zawiera ankiety filistrów. Mają one formę formularzy, jednakże $\mathrm{z}$ racji na liczne informacje o charakterze biograficznym, zostały wstępnie przypisane przez autora do ww. grupy tematycznej. Nie jest to zresztą jedyna ewidencja - zachowały się również autobiografie (curriculum vitae) osób, które nie zostały przyjęte do Konwentu (F.160-224), tych, które były przez jakiś czas jego członkami (F.160-331), oraz osób z niego wykluczonych (F.160-225).

O członkach zresztą wiele mówią również księgi obecności. Są one bardzo ciekawym źródłem, tym bardziej, iż zachowały się wyłącznie w BLAN. Chronologicznie obejmują okres od marca 1921 do końca roku 1938, z niewielkimi tylko lukami. W kilku przypadkach równocześnie były prowadzone dwie księgi obecności ${ }^{24}$. Niestety kolejność umieszczenia ich w zespole wydaje się całkowicie przypadkowa. Cel ich powstania był wieloraki, co też zostało zaznaczone we wstępie do księgi z lat 1932-1933:

Po co księga podpisów?

1. By każdy obecny w Konwencie mógł złożyć w niej podpis.

2. By z księgi tej każdy zainteresowany mógt się dowiedzieć: kto byt i może coś miat do zakomunikowania innym.

3. By ipso facto można byto w kilku słowach powiadomić o wypadkach, potrzebie itp. Zainteresowanych.

4. By z księgi można czytać życie Konwentu.

5. By nie sprawiała ona złego wrażenia na osoby majace zmyst estetyki zbyt rozwinięty.

6. By w księdze tej zachowane byty warunki: oszczędność, porządek i czystość.

\footnotetext{
23 W tej jednostce znajduje się również m.in. zapis postanowień z zebrania porozumiewawczego odbytego między Konwentem, Arkonią, Welecją, Sarmatią i Jagiellonią; F.160-76, k. 13-17.

24 Dla przykładu jednostka F.160-261 obejmuje okres od 25 lutego 1925 r. do 27 stycznia 1926 r. W tym samym czasie prowadzono dodatkowo księgi obejmujące okres: od 11 listopada 1924 r. do 3 maja 1925 r. (F.160-264), od 3 maja 1925 do 1 października 1925 r. (F.160-263), od 10 października 1925 r. do 5 listopada 1925 r. (F.160-262). Chronologicznie następna księga obejmuje okres od 28 stycznia 1926 r do 15 maja 1926 r., jest więc bezpośrednią kontynuacją F.160-261.
} 
Czego tu robić nie wolno?

1. Bazgrać!

2. Plamić!

3. Wydzierać kartki.

4. Wypisywać gtupstwa.

A wszystko z myślą: ,Jak Cię widzą, tak Cię piszą”

Co innego, że winni będa pociagani do odpowiedzialności przed Sąd K!

Pamiętajcie! $!^{25}$

Jak zaznaczali sami członkowie, celem prowadzenia ksiąg miało być zachowanie informacji o życiu wewnętrznym Konwentu; i cel ten został zrealizowany. Poza informacją o obecności na spotkaniach kwaterowych można tam odnaleźć różnego typu notki informacyjne/polecenia dla członków - przez co odnosi się wrażenie, iż księgi te pełniły funkcję niejako tablicy informacyjnej. Oprócz tego było to miejsce, gdzie Polonusi mogli dać wyraz swoim talentom pisarskim i rysunkowym - ozdabiają je liczne rysunki, karykatury, wiersze oraz sztuki teatralne.

Część omawianych ksiąg (F.160-292 - F.160-295, F.160-300 - F.160-302) została opatrzona dodatkowym komentarzem przez osobę opracowującą: имеются порнографические рисунки, zwracając uwagę na rubaszny charakter części rysunków.

Kolejny dział stanowią referaty, które zachowały się w znacznej ilości. Wygłaszali je członkowie Konwentu (F.160-146 - F.160-199), przede wszystkim fuksi, ale również barwiarze. Ich tematyka była różnorodna, począwszy od zagadnień dotyczących dziejów Konwentu (np. referat Witolda Kisiela dotyczący Stulecia Konwentu ${ }^{26}$ ) poprzez zagadnienia historyczne i społeczne. Zresztą, jeśli chodzi o działalność pisarską Konwentowiczów, zachowały się także liczne notatki z wykładów (F.160-332 - F.160-360, F.160-362 - F.160-383, F.160-401 - F.160-404), przede wszystkim te sporządzone przez studenta teologii Henryka Tochtermanna, z czego większość w języku niemieckim.

Jako ostatnie zostaną omówione materiały, które nie podzielono na odrębne grupy tematyczne - bynajmniej nie z powodu ich małej wartości merytorycznej, co z faktu, iż z racji na swoją różnorodność i unikalność nie można ich zaklasyfikować do żadnej z powyższych grup. Składają się na nie:

- Szopka konwentowa autorstwa Jana Niedziałkowskiego z dnia 21 marca 1936 r. (F.160-70)

- Polskie pieśni ludowe, spisane przez Olgierda Tarkiewicza w majątku Drabiszki powiat wiłkomierski (F.160-75)

- Materiały dotyczące bali organizowanych przez Konwent w latach 1911 oraz 1914 (F.160-77)

- Cztery fotografie przedstawiające kwaterę przy Rathaustrasse oraz grupę członków Konwentu z 1911 r. (F.160-84)

- Druki m.in. „Korporant”, „Wiadomości Korporacyjne” (F.160-85)

BLAN, F.160-282, k. 1.

26 BLAN, F.160-147. 
- Materiały dotyczące kodyfikacji: Praw Konwentu oraz Kodeksu Honorowego (F.160-129)

- Projekty i szkice kwatery mebli, mundurów i in. (F.160-133)

- Wykaz ruchomości Konwentu z 1922 r. (F.160-141)

- Dokumentacja osobista i rodzinna Konrada Niedziałkowskiego ${ }^{27}$ z lat 1841-1926 (F.160-200, F.160-201)

- Wzory herbów korporacji: Viginita i Karpatia (F.160-253)

- Indeks studenta Uniwersytetu Jurjewskiego studiującego w latach 1895-1901 (F.160-323)

- Różne drobne dokumenty konwentowe - w tym korespondencja (F.160-361)

- Fragment sztuki teatralnej „Jordan” autorstwa Edwarda Żeligowskiego (F.160-388)

- Traktat historii prawa rzymskiego (F.160-389)

- Herniologie nach dem Vortrage von prof. Eduard von Wahl (F.160-390)

- Program Pierwszego Kongresu Naukowego Polskiej Młodzieży Akademickiej z 1931 r. (F.160-398)

Warto podkreślić, iż omówiony zespół jest niezwykle obszerny, zaś największą wartość stanowi przebogaty zbiór korespondencji. Natomiast nie zgromadzono w nim niemalże żadnych fotografii - zaledwie te znajdujące się w jednostce F.160-84, a także pojedyncze dołączane do innej dokumentacji. Dlatego też badacz może uzyskać pełną wartość informacyjną z przechowywanej dokumentacji dopiero, kiedy zapozna się z pozostałymi zbiorami warszawskimi i londyńskimi.

Pomijając kwestię dość dokładnego opisania życia codziennego korporacji i korporantów, wartość tego zespołu tkwi przede wszystkim w fakcie, iż jako jedyny zachował się tak kompletny. Z perspektywy archiwisty można być wdzięcznym członkom Konwentu, że pomimo planów przeniesienia swojej siedziby do Warszawy tuż po I wojnie światowej, ostatecznie zdecydowali się działać na terenie Wilna. Dzięki temu uniknęli losu innych warszawskich archiwów i kompletnej fragmentaryzacji swoich zbiorów.

\section{Characteristics of the archival fond of „Konvento Polonia aktai” from the Wroblewski Library of the Lithuanian Academy of Sciences Summary}

After World War II documentation of archive of the Konwent Polonia was dispersed. Currently, it is gathered in three institutions: The Archdiocesan Archive of Warsaw, The Wroblewski Library of the Lithuanian Academy of Sciences in Vilnius and The Polish Institute and Sikorski Museum in London. This study presents a Vilnius collection - both structure of the archival fond and the information value of gathered archival units. It is extremely useful for researchers - particularly in the context of the lack of online inventories, as well as factual mistakes committed during the archival description of the records gathered there.

This archival fond consists of 404 units and it is one of the most important sources for the history of both the Konwent Polonia and polish fraternities. Especially that most of fraternities archives were destroyed, and the total number of members of all academic fraternities until the outbreak of World War II was at least over a twelve thousand.

27 Konrad Niedziałkowski - ojciec członka Konwentu Jana Niedziałkowskiego. 
Keywords: Konwent Polonia, archive science, academic fraternity, Vilnius, student associations

Nota o Autorze: dr Karol Dowgialo - archiwista, specjalista z zakresu archiwistyki i dziejów korporacji akademickich, ponadto zainteresowany tematyką wojskowości średniowiecznej. 